\title{
Pengaruh Leverage dan Pertumbuhan Aset Terhadap Kebijakan Dividen Pada Perusahaan Manufaktur yang Terdaftar di BEI
}

\author{
Vindiani Sabrina \\ Program Studi Pendidikan Akuntansi, FPEB, Universitas Pendidikan Indonesia, Bandung, Indonesia
}

\begin{abstract}
This study aims to determine the effect of leverage and asset growth on dividend policy. The object of this study is a manufacturing company listed on the Stock Exchange for 5 years from 2010 to 2014. The research method used is descriptive and verification method. The population of this study is 150 manufacturing companies listed on the Stock Exchange. The sampling technique used purposive sampling technique so that a sample of 71 companies was obtained. The data collection technique used is a study of documentation on the financial statements of manufacturing companies listed on the IDX. Data analysis techniques were carried out by carrying out normality tests, multicollinearity tests, heteroscedasticity tests, and autocorrelation tests. The statistical analysis used in this study is multiple linear regression analysis for panel data with the help of application Eviews 9. Based on the test, it was found that there were no variables deviating from the classical assumptions. The results showed that leverage had a negative and significant effect on dividend policy and asset growth had a negative and significant effect on dividend policy.

Keywords. dividend policy; leverage; asset growth
\end{abstract}

\begin{abstract}
Abstrak
Penelitian ini bertujuan untuk mengetahui pengaruh leverage dan pertumbuhan aset terhadap kebijakan dividen. Objek pada penelitian ini adalah perusahaan manufaktur yang terdaftar di BEI selama 5 tahun dari 2010 sampai dengan 2014. Metode penelitian yang digunakan adalah metode deskriptif dan verifikatif. Populasi dari penelitian ini adalah perusahaan manufaktur yang terdaftar di BEI sebanyak 150 perusahaan. Teknik pengambilan sampel menggunakan teknik purposive sampling sehingga diperoleh sampel sebanyak 71 perusahaan. Adapun teknik pengumpulan data yang digunakan adalah studi dokumentasi terhadap laporan keuangan perusahaan manufaktur yang terdaftar di BEI. Teknik analisis data dilakukan dengan melakukan uji normalitas, uji multikolinearitas, uji heteroskedastisitas, dan uji autokorelasi. Analisis statistik yang digunakan dalam penelitian ini adalah teknik analisis regresi linier berganda untuk data panel dengan bantuan aplikasi Eviews 9. Berdasarkan pengujian diperoleh hasil bahwa tidak ditemukan adanya variabel yang menyimpang dari asumsi klasik. Hasil penelitian menunjukkan bahwa leverage berpengaruh negatif dan signifikan terhadap kebijakan dividen dan pertumbuhan aset berpengaruh negatif dan signifikan terhadap kebijakan dividen.
\end{abstract}

Kata kunci. kebijakan dividen; leverage; pertumbuhan asset.

Corresponding author. Email. vindianis.vs@gmail.com

How to cite this article. Sabrina, V. (2017). Pengaruh Leverage dan Pertumbuhan Aset Terhadap Kebijakan Dividen Pada Perusahaan Manufaktur yang Terdaftar di BEI. Jurnal Pendidikan Akuntansi Dan Keuangan, 5(2), 89-97. Retrieved from http://ejournal.upi.edu/index.php/JPAK/article/view/15407

History of article. Received: Februari 2017, Revision: Mei 2017, Published: Juli 2017

\section{Pendahuluan}

Pasar finansial dalam sistem keuangan Indonesia terbagi menjadi dua sistem, yaitu sistem moneter (perbankan) dan sistem non moneter (pasar modal dan lainnya). Salah satu instrumen keuangan dalam pasar modal adalah saham, dengan keuntungan yang ditawarkan berupa capital gain dan dividen. Pembagian dividen tentunya berkaitan dengan penentuan kebijakan dividen. Perusahaan ingin membagikan keuntungan yang diperolehnya kepada para pemegang saham dalam bentuk dividen, karena jika perusahaan ingin menahan sebagian besar dari pendapatannya sebagai laba ditahan maka bagian laba pendapatan yang tersedia untuk dividen semakin kecil. Perusahaan enggan melakukan pemotongan terhadap dividen karena akan mempengaruhi minat investor terhadap saham perusahaan yang bersangkutan. Menurut Signalling Theory, harga saham akan turun dengan diumumkannya pemotongan dan penghapusan 
dividen. Tetapi di sisi lain, pembagian dividen yang tinggi kurang disukai oleh manajemen karena akan mengurangi dana untuk investasi. Hal ini sesuai dengan Residual Theory menurut Karen (2003) yang menyatakan bahwa Kelebihan kas yang ada seharusnya dibagikan dalam bentuk dividen, akan tetapi manajemen tidak menyukai pembagian laba yang diperoleh dalam bentuk dividen. Manajemen lebih suka memperlakukannya sebagai laba ditahan, kecuali mengetahui bahwa dana tersebut tidak memberikan net present value (NVP) yang positif pada tambahan investasi. Kebijakan dividen merupakan kebijakan yang sulit juga dilematis bagi pihak manajemen perusahaan, sebab kebijakan tersebut berkaitan dengan dua tujuan yaitu untuk memaksimalkan kekayaan para pemegang saham dan untuk pembiayaan yang cukup. Kebijakan pembagian dividen di perusahaan mengikuti besarnya laba yang diperoleh oleh perusahaan. Semakin besar laba yang diperoleh, semakin besar dividen yang dibayarkan dan sebaliknya. Warsono (2003:275) menyatakan rasio yang mengukur perbandingan dividen terhadap laba perusahaan disebut rasio pembayaran dividen (Dividend Payout Ratio). Berikut ini merupakan data Dividend Payout Ratio pada perusahaan manufaktur yang terdaftar di BEI dari tahun 2010 sampai dengan tahun 2014:

Tabel 1. Data Dividend Payout Rati Perusahaan Manufaktur

\begin{tabular}{ccccc}
\hline \multirow{2}{*}{ No } & \multirow{3}{*}{ Kode } & \multicolumn{2}{c}{$\begin{array}{c}\text { Dividend Payout } \\
\text { Ratio (\%) }\end{array}$} & \multirow{2}{*}{$\begin{array}{c}\text { Rata- } \\
\text { rata }\end{array}$} \\
\cline { 3 - 4 } & & $\mathbf{2 0 1 3}$ & $\mathbf{2 0 1 4}$ & \\
\hline 1. & ALMI & 44.16 & 23.58 & 33.87 \\
2. & DPNS & 23.39 & 11.44 & 17.42 \\
3. & EKAD & 17.65 & 14.29 & 15.97 \\
4. & TRST & 45.45 & 41.67 & 43.56 \\
5. & SCCO & 30.34 & 29.47 & 29.90 \\
6. & SKLT & 26.02 & 24.15 & 25.09 \\
7. & HMSP & 100 & 98.46 & 99.23 \\
8. & KLBF & 55.63 & 41.46 & 48.55 \\
9. & TSPC & 53.57 & 53.19 & 53.38 \\
10. & TCID & 49.47 & 46.48 & 47.97 \\
\hline
\end{tabular}

Sumber: Laporan Keuangan Perusahaan Tercatat di BEI (diolah kembali)

Pada tahun 2014 sebagian besar (59\%) perusahaan mengalami penurunan DPR. Hal ini disinyalir karna pada tahun 2014 situasi industri manufaktur tengah mengalami goncangan. Mengutip lama Financial Times (3/11/2014), indeks pembelian manajer (PMI) sektor manufaktur Indonesia melemah ke level 49,2 dari 50,7 pada September (www.bisnis.liputan6.com).

Penurunan jumlah dividen yang
dibagikan mempunyai dampak bagi perusahaan dan investor. Bagi perusahaan yang bersangkutan, penurunan dividen menyebabkan nilai perusahaan yang turun ditandai dengan turunnya harga saham. Perusahaan juga dipandang tidak dapat meningkatkan kekayaan para pemilik perusahaan. Selain itu, penurunan pembayaran dividen menandakan perusahaan menahan sebagian besar dari pendapatannya sebagai laba ditahan untuk membiayai operasional dan investasi di perusahaan. Apabila Investasi yang dilakukan perusahaan mengalami kegagalan atau tidak memberikan keuntungan yang diharapkan, maka akan menyebabkan perusahaan merugi. Jika nantinya perusahaan akan menerbitkan saham baru untuk memperoleh dana dari para investor, perusahaan akan mengalami kesulitan karena minat investor terhadap perusahaan telah berkurang.

Menurut Riyanto (2013:267) faktorfaktor yang mempengaruhi kebijakan dividen suatu perusahaan adalah posisi likuiditas perusahaan, kebutuhan untuk membayar hutang, tingkat pertumbuhan perusahaan, dan pengawasan terhadap perusahaan. Berdasarkan faktor-faktor yang mempengaruhi kebijakan dividen di atas, peneliti mengambil dua faktor yaitu kebutuhan untuk membayar hutang dan tingkat pertumbuhan perusahaan.

Untuk mengetahui seberapa jauh hutang perusahaan ialah dengan menggunakan rasio leverage. Indikator leverage yang digunakan yaitu Debt to Equity Ratio (DER) yang merupakan rasio yang mengukur seberapa jauh perusahaan dibiayai oleh hutang, dimana menurut Sartono (2001:66) semakin tinggi rasio ini menggambarkan gejala yang kurang baik bagi perusahaan. Peningkatan hutang akan mempengaruhi besar kecilnya laba bersih yang tersedia bagi para pemegang saham termasuk dividen yang diterima karena kewajiban untuk membayar hutang lebih diutamakan daripada pembagian dividen. 
Faktor selanjutnya yang diduga berpengaruh terhadap kebijakan dividen adalah pertumbuhan aset. Aset merupakan aktiva yang digunakan untuk aktivitas operasional perusahaan. Menurut teori residual dividen, perusahaan akan membayar dividennya jika hanya tidak memiliki kesempatan investasi yang menguntungkan. Perusahaan dapat melakukan ekspansi dengan pembelian aset. Jika perusahaan melakukan ekspansi, maka dana yang diperoleh dari perusahaan dan dana yang dapat digunakan untuk pembayaran dividen dapat berkurang. Sehingga pertumbuhan aset berpengaruh negatif terhadap pembayaran dividen.

\section{Landasan Teori}

\section{Dividen}

Menurut Stice et al (2004:902) menyatakan bahwa dividen adalah pembagian kepada pemegang saham dari suatu perusahaan secara proporsional sesuai dengan jumlah saham yang dipegang oleh masingmasing pemilik. Menurut Hanafi (2004:361), dividen merupakan kompensasi yang diterima oleh pemegang saham, disamping capital gain.

\section{Kebijakan Dividen}

Kebijakan dividen merupakan bagian yang tidak dapat dipisahkan dengan keputusan pendanaan perusahaan. Menurut Martono dan Harjito (2005:253), kebijakan dividen adalah keputusan apakah laba yang diperoleh perusahaan pada akhir tahun akan dibagi kepada pemegang saham dalam bentuk dividen atau akan ditahan untuk menambah modal guna pembiayaan investasi di masa yang akan datang.

Indikator yang digunakan untuk mengukur kebijakan dividen menurut Warsono (2003:275) salah satunya adalah dividend payout ratio yang merupakan hasil perbandingan antara dividen dengan laba yang tersedia bagi para pemegang saham biasa. Dividend Payout Ratio (DPR) dapat dihitung dengan menggunakan rumus sebagai berikut:

Dividend Payout Ratio $=\frac{\text { Dividend per Share }}{\text { Earning per share }}$

\section{Leverage}

Husnan (2006:70) mengemukakan rasio leverage ialah rasio yang mengukur seberapa jauh perusahaan menggunakan hutang. Menurut Fahmi, I (2011:127) rasio leverage adalah mengukur seberapa besar perusahaan dibiayai dengan hutang.

Dalam penelitian ini indikator yang digunakan untuk menggambarkan leverage adalah Debt to Equity Ratio (DER). DER adalah rasio leverage yang menggambarkan sejauh mana perusahaan menggunakan hutangnya dibanding modal sendiri Irham (Fahmi, 2011:127).

$$
\text { DER }=\frac{\text { Total Hutang }}{\text { Modal }} \times 100 \%
$$

Berdasarkan aturan finansial konservatif (Riyanto, 2013:23) menyatakan bahwa besarnya hutang dalam keadaan bagaimanapun juga tidak boleh melebihi besarnya modal sendiri. Koefisien hutang, yaitu angka perbandingan antara jumlah modal asing dengan modal sendiri tidak boleh melebihi 1:1.

Semakin tinggi DER, komposisi hutang juga semakin tinggi, sehingga akan berakibat pada semakin rendahnya kemampuan untuk membayar dividen. Menurut Riyanto (2013:267), apabila perusahaan menetapkan bahwa pelunasan hutangnya akan diambil dari laba ditahan, berarti perusahaan harus menahan sebagian besar dari pendapatannya untuk keperluan tersebut, hal ini berarti bahwa hanya sebagian kecil saja dari pendapatan yang dapat dibayarkan sebagai dividen. Sehingga setiap kenaikan debt to equity ratio akan mengakibatkan dividend payout ratio akan semakin rendah.

\section{Pertumbuhan Aset}

Dalam menjalankan operasinya, perusahaan tidak akan terlepas dari aset. Menurut Hanafi (2004:24) aset adalah sumber daya yang dikuasai oleh perusahaan sebagai akibat dari peristiwa masa lalu dan manfaat ekonomi di masa depan yang diharapkan akan diraih oleh perusahaan. Sehingga dapat disimpulkan bahwa aset merupakan sumber daya baik berwujud maupun tidak berwujud yang dimiliki oleh perusahaan.

Pertumbuhan perusahaan dapat dilihat dari pertumbuhan asetnya. Menurut Halim, A (2005:42), "pertumbuhan aset adalah perubahan (tingkat pertumbuhan) tahunan dari total aset". Tingkat pertumbuhan aset dihitung dengan proporsi perubahan aset dari suatu 
periode tahunan ke periode tahunan berikutnya. Menurut Abdul Halim (2005:42).

Asset Growth $=\frac{\text { Total Aktiva } t-\text { Total Aktiva }_{\mathrm{t}-1}}{\text { Total Aktiva }}$

Semakin besar aset diharapkan semakin besar pula hasil operasional yang dihasilkan oleh suatu perusahaan. Namun, bila prosentase perubahan total aset dari suatu periode ke periode berikutnya tinggi, maka semakin besar risiko yang akan ditanggung oleh pemegang saham. Menurut teori residual deviden, perusahaan akan membayar devidennya jika hanya tidak memiliki kesempatan investasi yang menguntungkan. Hal ini sejalan dengan yang dikemukakan oleh Husnan, S (2006:304) bahwa besarnya dividen yang dibagikan akan dipengaruhi oleh ada tidaknya kesempatan investasi yang menguntungkan. Sejauh terdapat kesempatan investasi yang menguntungkan, maka dana yang diperoleh dari perusahaan akan dipergunakan untuk mengambil investasi tersebut. Jika terdapat sisa, barulah sisa tersebut dibagikan sebagai dividen.

\section{Metode Penelitian}

Metode yang digunakan adalah metode deskriptif dan verifikatif. Metode deskriptif dan verifikatif adalah penelitian yang menggambarkan fakta-fakta, sifat-sifat dan hubungan antar variabel dalam upaya membuktikan kebenaran teori yang telah ada atau hipotesis yang telah dibuat.

Variabel bebasnya adalah leverage dan pertumbuhan aset. Variabel terikatnya adalah kebijakan dividen. Populasinya adalah seluruh perusahaan manufaktur yang terdaftar di BEI yaitu sebanyak 150 perusahaan.

Penelitian akan dilakukan terhadap laporan keuangan 71 sampel perusahaan selama periode 2010-2014 yaitu 5 tahun. Maka data observasi pada penelitian ini berjumlah 355 data.

\section{Uji Asumsi Klasik}

Dalam penelitian ini pengujian hipotesis akan dilakukan dengan uji regresi multipel. Uji regresi multipel dilakukan untuk mengetahui arah pengaruh dua atau lebih variabel dependen terhadap variabel independen. Menurut Firdaus (2004:96) untuk menggunakan model regresi perlu dipenuhi beberapa asumsi, yaitu datanya berdistribusi normal tidak ada autokorelasi (berlaku untuk data time series), tidak terjadi heteroskedastisitas dan tidak ada multikolinearitas

Perumusan regresi linier multipel harus memenuhi persyaratan BLUE (Best, Linier, Unbiased, Estimator), yaitu pengambilan keputusan melalui uji $\mathrm{F}$ dan Uji t tidak boleh bias, untuk mendapatkan hasil yang BLUE maka harus dilakukan pengujian asumsi klasik.

\section{Uji Regresi Data Panel}

Data panel merupakan gabungan antara data cross-section (silang) dengan data time-series (deret waktu). Analisis regresi dengan data panel dapat dilakukan dengan beberapa metode. Menurut Yamin (2011:200) metode tersebut adalah:

\section{Metode Common Effect}

Pendekatan ini tidak memperhatikan dimensi individu atau waktu. Dalam estimasi common effect diasumsikan bahwa intersep dan slope (koefisien regresi) tetap untuk setiap perusahaan dan waktu.

\section{Metode Fixed Effect}

Metode ini mengasumsikan bahwa perusahaan memiliki intersep yang berbeda, tetapi memiliki slope regresi yang sama. Untuk membedakan antara perusahaan satu dengan yang lainnya digunakan variabel dummy (variabel contoh/semu) sehingga metode ini disebut Least Square Dummy Variables $(L S D V)$.

\section{Metode Random Effect}

Model ini mengasumsikan bahwa setiap variabel mempunyai perbedaan intersep, tetapi intersep tersebut bersifat random atau stokastik.

Dari metode-metode di atas, akan dipilih satu metode yang paling tepat untuk analisis data panel. Langkah-langkah menentukan model dalam regresi dengan data panel adalah sebagai berikut:

\section{Uji Chow}

Uji Chow dilakukan untuk memilih model mana yang lebih baik, apakah common effect atau fixed effect. Bila $\mathrm{H}_{0}$ ditolak, lanjutkan dengan meregresikan data panel dengan metode random effect. Bandingkan model 
regresi mana yang akan digunakan dengan Uji Hausman.

\section{Uji Hausman}

Hausman mengembangkan suatu uji untuk memilih apakah menggunakan model fixed effect atau random effect yang lebih baik. ika $p$ value > 5\% maka kita menerima $\mathrm{H}_{0}$, yang artinya menggunakan model random effect, dan sebaliknya. Apabila hasil Uji Chow menunjukkan model common effect dan Uji Hausman menunjukkan random effect maka dilakukan uji yang ketiga yaitu Uji Lagrange Multiplier (Uji LM).

\section{Uji Lagrange Multiplier (Uji LM)}

Uji LM digunakan untuk mengetahui apakah model random effect lebih baik dari metode OLS atau common effect. Uji LM didasarkan pada nilai residual dari metode OLS. Jika nilai LM statistik lebih besar dari nilai kritis statistik chi-squares maka $\mathrm{H}_{0}$ ditolak, dan menggunakan model random effect.

\section{Uji Keberartian Regresi (Uji F)}

Uji F menguji signifikansi pengaruh seluruh variabel bebas terhadap variabel terikat sekaligus tanpa memperhatikan tingkat pengaruh dari setiap variabel secara terpisah. Hipotesis dalam penelitian ini:

$$
\begin{array}{ll}
\mathrm{H}_{0} & \text { : Regresi Tidak Berarti } \\
\mathrm{H}_{1} & \text { : Regresi Berarti }
\end{array}
$$

\section{Uji Keberartian Koefisien Regresi (Uji t)}

Uji keberartian koefisien regresi (Uji t) menunjukkan pengaruh satu variabel independen secara individual terhadap variabel terikatnya dengan menganggap variabel independen lainnya bernilai tetap. Hipotesis dalam penelitian ini adalah:

- Untuk Variabel Independen X (Leverage)

$\mathrm{H}_{0}: \beta_{1} \geq 0$, tidak ada pengaruh leverage terhadap kebijakan dividen.

$\mathrm{H}_{1}: \beta_{1}<0$, terdapat pengaruh negatif leverage terhadap kebijakan dividen.

- Untuk Variabel Independen X (Pertumbuhan Aset)

$\mathrm{H}_{0}: \beta_{2} \geq 0$, tidak ada pengaruh pertumbuhan aset terhadap kebijakan dividen.
$\mathrm{H}_{1}: \beta_{2}<0$, terdapat pengaruh negatif pertumbuhan aset terhadap kebijakan dividen.

\section{Hasil dan Pembahasan}

\section{Leverage}

Leverage merupakan gambaran kemampuan perusahaan dalam menggunakan hutang. Rasio ini dapat melihat seberapa jauh perusahaan dibiayai oleh utang atau pihak luar dengan kemampuan perusahaan yang digambarkan oleh modal. Dalam penelitian ini, leverage diukur dengan menggunakan Debt to Equity Ratio (DER). Rasio DER adalah rasio hutang dengan modal sendiri. Semakin tinggi rasio ini berarti modal sendiri semakin sedikit dibanding dengan hutangnya.

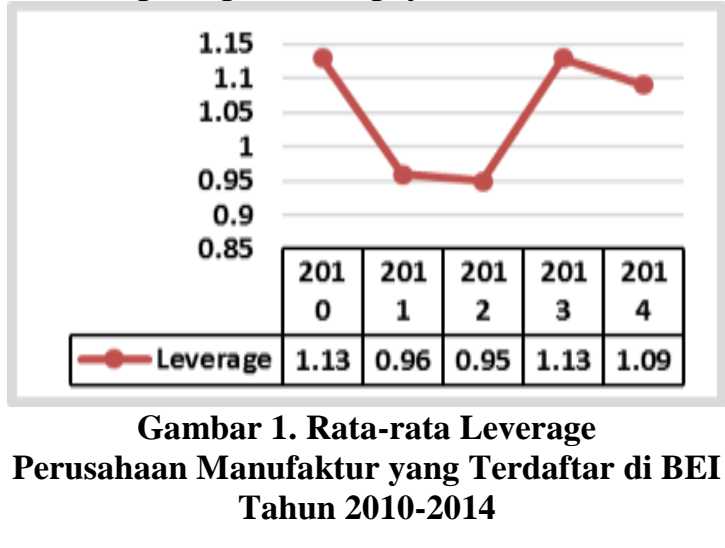

Berdasarkan gambar 4.1 dapat diketahui bahwa nilai rata-rata leverage perusahaan manufaktur pada tahun 2010 adalah sebesar 1,13 atau $113 \%$. Pada tahun 2011 nilai rata-rata leverage mengalami penurunan sebesar 0,07 sehingga nilainya menjadi 0,96 atau $96 \%$. Pada tahun 2012 rata-rata leverage mengalami penurunan kembali sebesar 0,01 sehingga nilainya menjadi 0,95 atau $95 \%$. Sedangkan pada tahun 2013 rata-rata leverage mengalami kenaikan sebesar 0.18 sehingga nilainya menjadi 1.13 atau 113\%. Dan pada tahun 2014 terjadi penurunan kembali sebesar 0,04 sehingga nilainya menjadi 1,09 atau 109\%.

Secara keseluruhan rata-rata leverage selama lima tahun dari tahun 2010 sampai dengan 2014 adalah sebesar 1,05 atau 105\%. Menurut aturan finansial mengenai koefisien utang, nilai maksimum leverage adalah $100 \%$, yang berarti perbandingan utang dengan modal ialah 1:1. Dilihat dari besarnya rasio leverage pada tabel 4.4, perusahaan yang memiliki nilai rata-rata leverage yang berada di atas nilai 
maksimum $100 \%$ adalah sebanyak 29 perusahaan. Sedangkan perusahaan yang memiliki nilai rata-rata leverage yang berada di bawah nilai maksimum $100 \%$ adalah sebanyak 42 perusahaan.

Perusahaan-perusahaan dengan nilai leverage lebih dari 100\% menunjukkan bahwa perusahaan memiliki jumlah hutang yang lebih besar dibandingkan dengan modal sendirinya. Yang juga berarti bahwa perusahaanperusahaan tersebut memiliki kemampuan yang tinggi untuk memenuhi kewajiban keuangannya dalam membayar hutang. Selain itu, dapat terlihat juga bahwa pendanaan pada perusahaan-perusahaan tersebut lebih banyak dibiayai oleh utang daripada modal sendiri.

Perusahaan-perusahaan dengan nilai leverage kurang dari $100 \%$ menunjukkan bahwa perusahaan-perusahaan tersebut memilih untuk lebih banyak menggunakan modal sendiri dibandingkan dengan hutang. Dengan lebih banyak menggunakan modal sendiri akan memperbesar kemampuan perusahaan dalam menanggung resiko usaha perusahaan yang akan dibelanjainya.

\section{Pertumbuhan Aset}

Pertumbuhan aset (asset growth) merupakan perubahan (tingkat pertumbuhan) tahunan dari total aset. Tingkat pertumbuhan aset dihitung dengan proporsi perubahan aset dari suatu periode tahunan ke periode tahunan berikutnya.

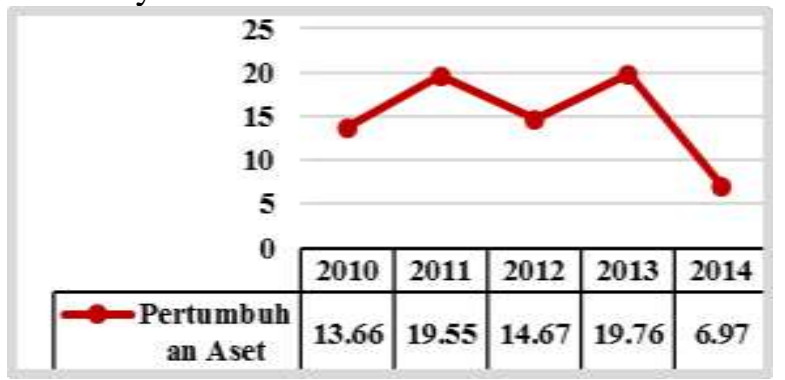

Gambar 2. Rata-rata Pertumbuhan Aset Perusahaan Manufaktur yang Terdaftar di BEI Tahun 2010-2014

Berdasarkan gambar 4.2 dapat diketahui bahwa pada tahun 2010 rata-rata pertumbuhan aset perusahaan manufaktur adalah sebesar 13,66\%. Pada tahun 2011 rata-rata pertumbuhan aset perusahaan manufaktur mengalami kenaikan sebesar 5,89\% sehingga nilainya menjadi 19,55\%. Pada tahun 2012 rata-rata pertumbuhan aset perusahaan manufaktur mengalami penurunan sebesar
$4,88 \%$ sehingga nilainya menjadi $14,67 \%$. Pada tahun 2013 rata-rata pertumbuhan aset perusahaan manufaktur mengalami kenaikan sebesar 5,09\% sehingga nilainya menjadi 19,76\%. Pada tahun 2014 rata-rata pertumbuhan aset perusahaan manufaktur mengalami penurunan sebesar $12,79 \%$ sehingga nilainya menjadi $6,97 \%$.

Pertumbuhan aset perusahaan manufaktur dari 71 perusahaan yang menjadi sampel dalam penelitian ini pada tahun 2010 sampai dengan 2014 mengalami fluktuatif dengan kecenderungan menurun. Hal ini terlihat dari perolehan rata-rata pertumbuhan aset perusahaan manufaktur yang mengalami perubahan setiap tahunnya.

Penurunan pertumbuhan aset perusahaan disinyalir karna situasi industri manufaktur pada tahun 2014 tengah mengalami guncangan. Mengutip laman Financial Times (3/11/2014), indeks pembelian manajer (PMI) sektor manufaktur Indonesia melemah ke level 49,2 dari 50,7 pada September (www.bisnis.liputan6.com). Laporan pelemahan indeks kegiatan manufaktur di Indonesia diperoleh dari laporan HSBC/Markit Purchasing Managers' Index. Survei tersebut melaporkan penurunan tersebut disebabkan melemahnya bidang produksi dan permintaan domestik maupun luar negeri.

\section{Kebijakan Dividen}

Kebijakan dividen adalah kebijakan yang berkaitan dengan keputusan apakah laba yang diperoleh perusahaan akan dibagikan kepada pemegang saham dalam bentuk dividen atau sebagai saldo laba untuk menambah modal guna pembiayaan investasi di masa yang akan datang. Dalam penelitian ini, kebijakan dividen diukur dengan Dividend Payout Ratio (DPR). Dividend Payout Ratio (DPR) merupakan rasio hasil perbandingan antara dividen dengan laba yang tersedia bagi para pemegang saham. Rasio pembayaran dividen (Dividend Payout Ratio) menunjukkan jumlah laba yang dapat dibagikan sebagai dividen. Semakin besar DPR maka semakin besar jumlah laba yang dibagikan sebagai dividen. 


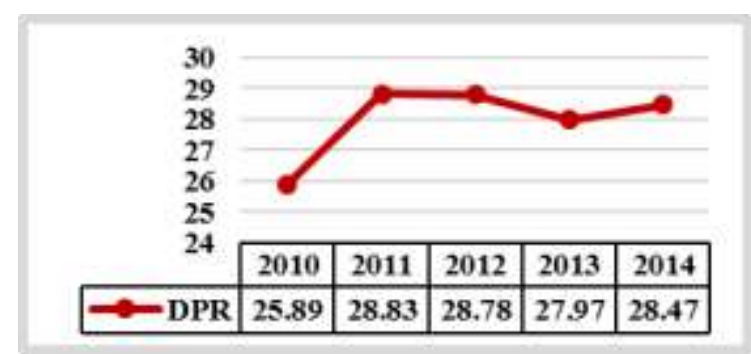

Gambar 4.3. Rata-rata Kebijakan Dividen Perusahaan Manufaktur yang Terdaftar di BEI Tahun 2010-2014

Berdasarkan gambar 4.3 dapat diketahui bahwa rata-rata pembagian dividen perusahaan manufaktur selama tahun 2010 higga tahun 2014 berfluktuasi. Pada tahun 2010 rata-rata nilai DPR perusahaan adalah 25,89\%. Pada tahun 2011 rata-rata nilai DPR perusahaan manufaktur mengalami kenaikan sebesar $2,94 \%$ sehingga nilainya menjadi $28,83 \%$. Pada tahun 2012 rata-rata nilai DPR perusahaan manufaktur mengalami penurunan sebesar $0,05 \%$ sehingga nilainya menjadi $28,78 \%$. Pada tahun 2013 rata-rata nilai DPR perusahaan manufaktur mengalami penurunan sebesar $0,81 \%$ sehingga nilainya menjadi $27,97 \%$. Pada tahun 2014 rata-rata nilai DPR perusahaan manufaktur mengalami kenaikan sebesar $0,5 \%$ sehingga nilainya menjadi $28,47 \%$.

Dilihat dari besarnya DPR perusahaanperusahaan manufaktur yang beragam, dapat disimpulkan bahwa perusahaan memutuskan kebijakan dividen yang berbeda-beda sesuai dengan kondisi perusahaan masing-masing pada periode yang bersangkutan. Perusahaan yang memiliki nilai DPR diatas $0 \%$ menunjukkan bahwa perusahaan tersebut memutuskan untuk membagikan sebagian atau seluruh laba dalam bentuk dividen kepada para pemegang saham. Sedangkan perusahaan yang memiliki nilai $\mathrm{DPR}=0 \%$ menunjukkan bahwa perusahaan memutuskan untuk menahan laba perusahaan.

Dari perhitungan uji asumsi klasik, tidak terdapat variabel yang menyimpang dari asumsi klasik. Penelitian ini digunakan data panel, yaitu gabungan antara data cross-section dan data time-series. Dari prosedur penelitian untuk data panel diperoleh hasil bahwa penelitian ini lebih baik menggunakan model Fixed Effect.

Dari pengujian hipotesis regresi data panel menggunakan model Fixed Effect dengan bantuan Eviews 9 diperoleh bahwa $\mathrm{F}_{\text {hitung }}>$ $\mathrm{F}_{\text {tabel }}$ yaitu 14,64779>3,02137, sehingga $\mathrm{H}_{0}$ ditolak dan $\mathrm{H}_{1}$ diterima. Hal tersebut menunjukkan bahwa model regresi dalam penelitian ini berarti dan dapat digunakan untuk membuat kesimpulan yang menggambarkan pengaruh leverage dan pertumbuhan aset terhadap kebijakan dividen.

\section{Pengaruh Leverage terhadap Kebijakan Deviden}

Untuk variabel leverage, diperoleh nilai $t_{\text {hitung }}(-0,963058)>t_{\text {tabel }}(-1,96673)$ maka $\mathrm{H}_{0}$ ditolak dan $\mathrm{H}_{1}$ diterima. Dan diketahui probabilitas sebesar 0,0363 lebih kecil dari 5\% sehingga bermakna signifikan. Maka kesimpulannya adalah terdapat pengaruh negatif dan signifikan leverage terhadap kebijakan dividen.

Kesimpulan hasil penelitian tersebut sesuai dengan teori-teori yang dikemukakan sebelumnya. Debt to Equity Ratio (DER) merupakan rasio yang mengukur seberapa jauh perusahaan dibiayai oleh hutang, dimana semakin tinggi rasio ini menggambarkan gejala yang kurang baik bagi perusahaan. Semakin tinggi debt to equity ratio, maka komposisi hutang juga akan semakin tinggi, sehingga akan berakibat pada semakin rendahnya kemampuan untuk membayar dividen. Menurut Riyanto (2013:267), apabila perusahaan menetapkan bahwa pelunasan hutangnya akan diambil dari laba ditahan, berarti perusahaan harus menahan sebagian besar dari pendapatannya untuk keperluan tersebut, yang ini berarti bahwa hanya sebagian kecil saja dari pendapatan yang dapat dibayarkan sebagai dividen. Dengan kata lain perusahaan harus menetapkan dividend payout yang rendah.

Peningkatan hutang akan mempengaruhi besar kecilnya laba bersih yang tersedia bagi para pemegang saham termasuk dividen yang diterima karena kewajiban untuk membayar hutang lebih diutamakan daripada pembagian dividen. Sehingga setiap kenaikan debt to equity ratio akan mengakibatkan dividend payout ratio akan semakin rendah.

Hasil penelitian ini juga sejalaan dengan penelitian sebelumnya yang dilakukan oleh Jannati, A (2012) yang menyatakan bahwa Debt to Equity Ratio berpengaruh negatif terhadap DPR. Semakin tinggi leverage maka akan menunjukkan semakin besar kewajiban yang dimiliki perusahaan. Sehingga leverage 
dapat mempengaruhi tingkat pendapatan bersih yang tersedia bagi para pemegang saham, yang artinya semakin besar kewajiban perusahaan akan menurunkan kemampuan perusahaan dalam pembayaran dividen.

Hutang yang cenderung tinggi juga menyebabkan tingginya beban bunga yang harus ditanggung perusahaan sehingga mengurangi kemampuan memperoleh laba bersih yang optimal yang berdampak pada pembayaran dividen yang lebih kecil kepada investor.

\section{Pengaruh Pertumbuhan Aset terhadap Kebijakan Dividen}

Untuk pertumbuhan aset, diperoleh nilai $t_{\text {hitung }}(-0,121129)>t_{\text {tabel }}(-1,96673)$ maka $H_{0}$ ditolak dan $\mathrm{H}_{1}$ diterima. Dan diketahui probabilitas sebesar 0,0037 lebih kecil dari 5\% sehingga bermakna signifikan. Maka kesimpulannya adalah terdapat pengaruh negatif dan signifikan pertumbuhan aset terhadap kebijakan dividen.

Kesimpulan hasil penelitian tersebut sesuai dengan teori-teori yang dikemukakan sebelumnya. Menurut teori residual deviden, perusahaan akan membayar devidennya jika hanya tidak memiliki kesempatan investasi yang menguntungkan, sehingga dapat disimpulkan bahwa terdapat hubungan yang negatif antara pertumbuhan aset dan pembayaran deviden. Hal ini sejalan dengan yang dikemukakan oleh Husnan, S (2006:304):

Besarnya dividen yang dibagikan akan dipengaruhi oleh ada tidaknya kesempatan investasi yang menguntungkan. Sejauh terdapat kesempatan investasi yang menguntungkan, maka dana yang diperoleh dari perusahaan akan dipergunakan untuk mengambil investasi tersebut. Kalau terdapat sisa, barulah sisa tersebut dibagikan sebagai dividen.

Menurut Hanafi (2008:44), perusahaan yang memiliki tingkat pertumbuhan yang tinggi akan memiliki rasio pembayaran dividen yang rendah. Pertumbuhan yang tinggi tersebut akan menyebabkan perusahaan membutuhkan dana yang besar untuk membiayai berbagai aktivitas investaso, ekspansi, dan lain-lain. Sehingga dana yang tersisa untuk dibagikan sebagai dividen akan semakin berkurang.

Hasil penelitian ini juga didukung dengan penelitian sebelumnya yang dilakukan oleh Jannati, A (2012) yang menyatakan bahwa pertumbuhan aset berpengaruh negatif terhadap kebijakan dividen. Semakin tinggi tingkat pertumbuhan perusahaan maka akan semakin besar tingkat kebutuhan dana untuk membiayai total aset perusahaan. Sehingga perusahaan akan lebih senang menahan labanya untuk membiayai ekspansi atau pertumbuhan perusahaan daripada dibayarkan dalam bentuk dividen kepada para pemegang saham. Dengan demikian dapat dikatakan bahwa semakin cepat tingkat pertumbuhan perusahaan, semakin besar dana yang dibutuhkan, semakin besar kesempatan untuk memperoleh keuntungan, semakin besar bagian dari pendapatan yang ditahan dalam perusahaan, maka akan semakin rendah dividend payout ratio-nya.

\section{Kesimpulan}

Berdasarkan hasil analisis dan pembahasan yang telah dilakukan dalam penelitian ini, maka dapat ditarik kesimpulan yaitu (1) Rata-rata leverage perusahaan manufaktur pada tahun 2010 sampai dengan tahun 2014 adalah 1,05 atau 105\%. Leverage tertinggi sebesar 7,40 atau $740 \%$ dimiliki oleh PT Jembo Cable Company Tbk (JECC) pada tahun 2013. Sedangkan nilai leverage terendah adalah sebesar 0,04 atau 4\% yang dimiliki oleh PT Jaya Pari Steel Tbk (JPRS) pada tahun 2014. (2) Rata-rata pertumbuhan aset perusahaan manufaktur pada tahun 2010 sampai dengan tahun 2014 adalah sebesar $14,92 \%$. Pertumbuhan aset tertinggi adalah sebesar 95,37\% yang dimiliki oleh PT KMI Wire and Cable Tbk (KBLI) pada tahun 2010. Sedangkan pertumbuhan aset terendah adalah sebesar $-47,79 \%$ yang dimiliki oleh PT Yana Prima Hasta Persada Tbk (YPAS) pada tahun 2014. (4) Rata-rata kebijakan dividen perusahaan manufaktur yang diukur dengan dividend payout ratio (DPR) selama lima tahun dari tahun 2010 sampai dengan tahun 2014 adalah sebesar $27,99 \%$. DPR tertinggi adalah sebesar $100 \%$ yang dimiliki oleh PT Unilever Indonesia Tbk pada tahun 2010, 2011 dan 2014 serta PT Hanjaya Mandala Sampoerna Tbk pada tahun 2013. Sedangkan nilai DPR terendah selama lima tahun adalah sebesar 0\% yang dimiliki oleh PT Keramika Indonesia Assosiasi Tbk, PT KMI Wire and Cable Tbk, PT Duta Pertiwi Nusantara Tbk, PT Alaska Industrindo Tbk, PT Jaya Pari Steel Tbk, PT Berlina Tbk, PT Fajar Surya Wisesa Tbk, PT Indofarma Tbk, PT Langgeng Makmur 
Industry Tbk, PT Indo Acitama Tbk, PT Berlina Tbk, PT Selamat Sempurna Tbk, PT Kabelindo Murni Tbk, dan PT Mustika Ratu Tbk. (5) Leverage memiliki pengaruh negatif dan signifikan terhadap kebijakan dividen. (6) Pertumbuhan aset memiliki pengaruh negatif dan signifikan terhadap kebijakan dividen.

\section{Daftar Pustaka}

Deil, S.A.F. (2014). Industri Manufaktur Indonesia Masih Lesu. [Online]. Diakses dari

http://bisnis.liputan6.com/read/2128208/in dustri-manufaktur-indonesia-masih-lesu

Fahmi, I. (2011). Analisis Laporan Keuangan. Lampulo: ALFABETA

Firdaus, M. (2004). Ekonometrika Suatu Pendekatan Aplikatif. Jakarta: Bumi Aksara

Halim, A. (2005). Analisis Investasi. Jakarta: Salemba Empat

Hanafi, M. M. (2004). Manajemen Keuangan. Yogyakarta: BPFE

Husnan, S., dan Pudjiastuti, E. (2006). Dasardasar Manajemen Keuangan. Edisi kelima. Yogyakarta: UPP STIM YKPN

Indonesia, B.E. (2015). Laporan Keuangan dan Tahunan. [Online]. Diakses dari http://www.idx.co.id/id-id/beranda/perusa haantercatat/laporankeuangandantahunan. aspx

Jannati, A. (2012). Pengaruh Profitabilitas, Leverage, Dan Growth Teradap Kebijakan Dividen (Sensus Pada Perusahaan Manufaktur Consumer Goods Industry yang listing di Bursa Efek Indonesia). (Skripsi). Tasikmalaya: FE UNSIL

Karen, F.R. (2003). A Blue Print for Corporate Governance. New York: American Management Assosiation.

Martono, D., dan Agus, H. (2005). Manajemen Keuangan. Yogyakarta: Penerbit Ekonisia

Riyanto, B. (2013). Dasar-Dasar Pembelanjaan Perusahaan, Edisi Keempat. Yogyakarta: BPFE
Sartono, A. (2001). Manajemen Keuangan "Teori dan Aplikasi". Yogyakarta: Penerbit BPFE-Yogyakarta

Stice, J., et al. (2004). Akuntansi Intermedite, Buku Satu, Edisi Limabelas. Jakarta: Salemba Empat.

Warsono. (2003). Manajemen Keuangan Perusahaan, Jilid Satu, Edisi Ketiga. Jakarta: Bayu Media

Yamin, et al. (2011). Regresi dan Korelasi dalam Genggaman Anda-Apikasi dengan software SPSS. EViews, MINITAB dan STATGRAPHICS. Jakarta: Salemba Empat 